\title{
PEREGRINE FALCON ATTACKS SNOW GOOSE
}

\author{
ROBERT W. NERO, Manitoba Wildlife Branch, Box 14, 1495 St. James Street, \\ Winnipeg, Manitoba. R3H 0W9
}

Although being aware that Peregrine Falcons occasionally tackle prey larger than themselves, I was astonished to see a Peregrine attack a mature Snow Goose. This took place on 9 May 1991, at about 4:55 p.m. I was driving towards a group of highrises in the Winnipeg suburb of Tuxedo, hoping to see an adult female Peregrine that had been frequenting that site for several days, when suddenly there it was, circling over the buildings. I pointed it out to JoAnne Joyce, who was riding with me, then I hastily drove onto a sidestreet and parked. I got out my binoculars and we watched as the bird circled overhead. It headed southwards. In the next moment a Snow Goose appeared, evidently attracting the Peregrine. An adult, white-phase bird, it was approaching rapidly from the southeast at a height of $100-200 \mathrm{~m}$. I noted that the goose had a few feathers missing from its wings, giving it a ragged look, but it flew steadily onwards, coming towards the Tuxedo mall complex and the nearby highrises.

The Peregrine headed towards the goose, rose higher, and then turned and followed it, now flying rapidly and gaining altitude. Then it dived upon the goose, striking it with considerable force whereupon the goose staggered but kept going. A few seconds after the Peregrine hit the goose a second time, again striking it hard on the lower back, causing the goose to go down at a steep angle. Unfortunately, both the goose and the falcon, which was right behind it, then went out of our sight behind the high- rises. A few seconds later, however, they reappeared, both slanting down to treetop level and, again, out of our sight. We jumped in the car and hurriedly drove around and into the Tuxedo mall parking lot. When we got there, the Peregrine was circling low overhead and then it flew off to the southeast as if it had lost interest. We looked briefly for the goose, and later I checked several times with friends in the Manitoba Wildlife Rehabilitation Organization to see if there had been any report of an injured Snow Goose, but nothing turned up. The goose likely survived the attack, but we do not know this for certain.

This particular Peregrine Falcon, which I presumed to be the same adult female frequenting this vicinity - and the falcon we saw was clearly a female by size - had been identified by Robert Berger, Winnipeg Peregrine Falcon worker, as the falcon that had overwintered this past season in downtown Winnipeg. It had been banded and released as a juvenile in July 1989 at Cedar Rapids, Iowa. Until the time of our observation of the attack on the goose, this individual had been on territory at the University of Manitoba campus, where it seemed to be heading when we last saw it. Paired with an adult male on the campus, in late June it apparently returned for at least one short visit to the Tuxedo buildings.

Although the Peregrine Falcon preys mainly on birds smaller than itself, occasionally it takes large prey. Ratcliffe 


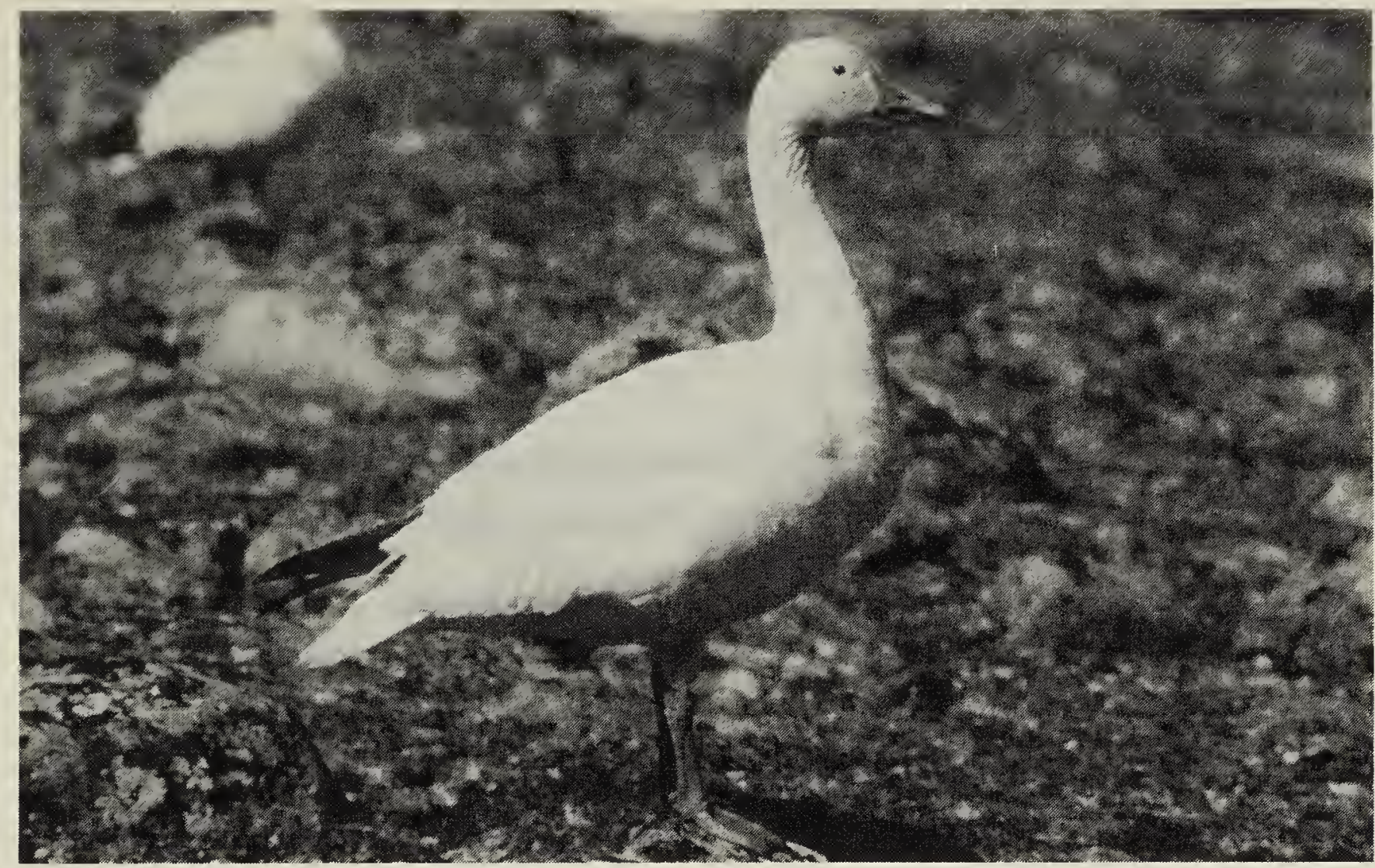

Lesser Snow Goose - not a small bird.

G.W.Beyersbergen

states: "The Peregrine is not only able to kill birds larger and heavier than itself, it can also sometimes carry them." $\mathrm{He}$ notes further: "The Peregrine is a powerful bird, the female in particular being heavy for its size, with a weight of up to $1350 \mathrm{~g}$; and the manner of its attack gives a capacity for knocking almost any other bird out of the sky." After seeing the Snow Goose episode, it was pleasing to read the following by the same author: "The biggest species seen to be struck down by a British Peregrine was a Greylag Goose ... the bird ... was seen to recover and fly away... Anything from this size downwards may be presumed at risk and birds as large as Barnacle Geese, Brent Geese, Shelduck, sawbill ducks and great Black-backed Gulls are certainly killed and eaten on occasions ... only birds such as swans and eagles ... seem to be exempt from predation."

Not even large raptors are safe. Forbush, quoted by Bent, states: "Audubon tells of a Snowy Owl which snatched a young duck hawk from its rocky perch, but was followed by the avenging parent, which quickly struck the larger bird dead."

Greg Septon recently described how a Peregrine pair at a Milwaukee nest site (41 storeys high) jointly went after a Turkey Vulture. The female tailed the vulture and harassed it while the male climbed about $400 \mathrm{~m}$ above it and then dropped upon it, causing it to tumble. A second stoop by the male brought the vulture to the ground. It is not known if the vulture was killed. ${ }^{3}$

1. BENT, A.C. 1938. Life histories of North American birds of prey. U.S. Natl. Museum Bull. 170, Part 2. Dover reprint, 1961.

2. RATCLIFFE, D. 1980. The Peregrine Falcon. Buteo Books, Vermillion, South Dakota. 416 pp.

3. SEPTON, G. 1991. Peregrine Falcon strikes Turkey Vulture. Passenger Pigeon 53: 192. 